\title{
Global English and New Sociocultural Concepts in Armenia
}

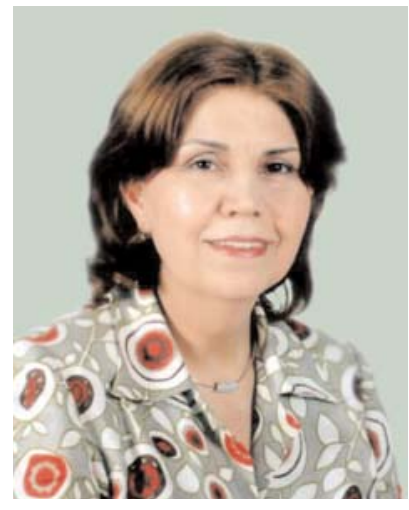

Nvard Yernjakyan

ワ $\mathrm{his}$ article aims at revealing and acknowledging Armenian and English linguistic manifestations of realias which have become salient as a result of the new managerial practices whose language is becoming English.

Along with almost all the former Soviet bloc countries, Armenia underwent a collapse and adopted a variant of "shock therapy", trying to introduce a series of major political and economic reforms as rapidly as possible. The Armenian collapse had its specific features: in 1991 the country became independent after the earthquake (1988) and with the Karabakh movement. Since that time the "Western countries" have begun supporting Armenia and its developing policies.

Changes, taking place in post-soviet Armenia, have currently influenced the sociolinguistic status of English, which, in its turn, has a direct impact on the objectives and perspectives of sociolinguistic research. Innovations in restructuring and rescaling of society told on local discourses which were once open to Russian but became now open mostly to English.

The universally recognized status of English as an international language, though not officially confirmed, doesn't need any proof, and its status as an adopted language of

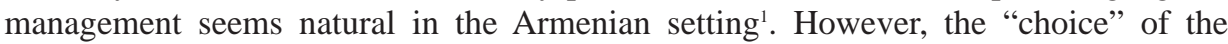
adopted form of government/management is beyond our competence. We are concerned with the understanding and interpretation of the linguistic problems of interwoven practices that arise in the result of English-Armenian interaction. The research is carried out with special reference to the sociolinguistic status of English.

In many respects our approach to analysis can be termed discourse-historical, focusing on the centrality of the language, because meaning relies on representation through language, and representation is different across cultures and historical periods. We proceed from the hypothetical assumption that foreign language discourse (acquisition and public discourse) $^{2}$ in the Armenian setting can be divided into four stages.

The first stage stretches from 1918 until about 1920, the end of the first Armenian Republic, whose language of public discourse (official/non-official) was Armenian.

The second stage, from the pre-Stalinist period including the Stalinist Soviet Armenia until 1953 (Stalin's death), is marked by the establishment of Soviet practices 
(ideological, economic and social order) created in Moscow in Russian. However, the official language of public discourse remained Armenian, it being a state language.

The third stage, from 1953 until around the independence, is marked by a tremendous expansion of Russian as a language of not only semi-official, professional and private communication but also a necessary prestigious attribute for the intelligentsia, though in fact Armenian remained the official language of public /managerial discourse.

The fourth stage following independence is, on the one hand, marked by the tendency of excluding Russian from official/public discourses and the establishment of the national language purism policy, and on the other, it was influenced by the processes of 'coming global' with the spread of 'global English' in Armenia. However, the Armenian language continues to be a state language and the language of public discourse as well.

During the first three stages English, along with other foreign languages, functioned mainly in educational and scientific spheres as well as translations and official contacts, all being controlled and censored by governing bodies, whereas in the present reality the business or partnership contacts are not either limited or directly controlled, and are available for all layers of society. Actually, the 'limit' today is dependent on language competence, and the communication between the partners needs to be translated either in writing (agreements, contracts, laws, etc.) or orally. International and intergovernmental agreements can be considered a basis, a legal argumentation to provide new management and, therefore, it is natural that a new managerial language ${ }^{3}$ is implemented in the economic and social life of the republic. Such organizations as UN, TASIS, USAID, World Bank, OXFAM, Peace Corpse office, etc., realizing different projects in Armenia, play an important role in establishing new managerial structures and working habits which provide the linguistic field with new concepts and terms. Thus, knowing English harmonizes with definitions like 'coming global', with the language of free market relations (as the new social-economic order in Armenia nowadays is likely to be called).

Under the pressure of the restructuring and rescaling of public management not only new words and concepts emerge and penetrate into Armenian but also new ways of acting and interacting are introduced into life. These new elements stimulate the occurrance of new linguistic transformations, which have different origins and habitat in local and adopted cultures. Thus, the following words and word combinations such as post-employment benefice, religious minoroties, community, community development, grant, presentations, monitoring, householder, homeless, etc., though peculiar to the official and public language, have found their equivalents in folk language as well: instead of saying Family poverty benefice, or Real estate fees, or Homeless, people just say Benefice, Renting fees, Bomjh ${ }^{4}$.

However, we think that the level of secondary education and awareness of the legal field cannot be considrerd the main reasons for the formation of people's perceptions and evaluations of the formal order and institutions.

It may probably be assumed that those who don't have power, create unofficial methods and procedures for the realization and defence of their interests in answer to their estrangement from power. These methods and procedures have their own language ${ }^{5}$ 
and system of moral justification safeguarding their parallel coexistance with the official language, procedures and publicly recognized morals. Coexistance of the official language of management and the unofficial language of people's social activity, vitally fundamental strategies and concepts, created in the process of interaction with authorities, change according to their own discretion ${ }^{6}$.

The denotation of the concept of an 'unofficial language of social activity' is not an end in itself but, as far as the phenomenon has to be somehow defined, we give our preference to "folk language", as a counterbalance to the "language of authorities"”.

Unlike Russian, which had already been widely used in Armenia for about a hundred years by the time of the Soviet power establishment, English as the language associated with curent democratic processes in the country doesn't have similar historical background. English has been and remains the language of professionals and translators, whose mediating mission is of special importance in the establishment of new institutions. However, the new institutions created by international and local experts are mainly for the citizens living in the present setting of Armenia. The mission of the adepts of globalization consists not only in transmitting the English managerial discourse into the Armenian reality, but also adapting it to the Armenian linguistic mentality. The mission is not an easy one, especially in the sense that there is a great difference between social and linguistic practices of generations.

For example, the associations of the statement he sold his flat are completely different for people of different generations, as the idea of private flats has been introduced into Armenian life only recently.

To fit the scope of the analysis within the confines of this article, we concentrate on the study of the metaphoric perception of home in both English and Armenian linguocultural traditions. The word and image characteristics of home allow us to trace three different connotations, in it: 1) of place, 2) of family, 3) of privacy.

The connotation of place is peculiar to both linguistic traditions. For example to go home (unntG qGuL), in which home is equalized to a proper name, like in the case of to go to town, i.e. a known place or one and the same place (in this respect it is relevant to refer to the Roman tradition, in which Rome was called Urbs - town).

The associative connotations of family in many ways are more vividly expressed in the Armenian culture. For example, to destroy home (to do harm to a family) or to keep the smoke alive (to beget a male child and provide prosperity to the family) in the Armenian tradition refer rather to the family than the physical object (the house).

The understanding of home as a physical object giving refuge to an individual at a certain period of time and providing his privacy is characteristic of the British culture and identity ${ }^{8}$.

With reference to 'coming global' in Armenia, with home/house in mind, it should be mentioned that apart from cultural symbolism, these notions have acquired socialeconomic significance for people.

Thus, legal and social economic discourses are in vanguard as far as after privatization public/managerial discourses as well as private communication became 
abundant in such terms as "household”, “householder's living status”, “condominium”, "accommodation service fees", "real estate fees", etc.

What is of special interest about housing in general and terms related is the objectword-meaning correlation, on the one hand, and peoples' perceptions and awareness of legal field, on the other. Some observations of public, managerial and legal spheres of community life have shown that by the inertia of the former Soviet social order regime, when people (urban population mainly) would feel owners, but in fact rented their homes from the state, nowadays being actual owners, still keep saying go to jhek (the Russian abbreviation for the governmental office in charge of domestic accommodation service), to pay the renting fees, hardly distinguishing between condominiums, private houses and private flats.

Another source of housing/domestic terms are the investigations coming out in the information analytical bulletins, numerous reports made by UNDP missions on poverty and the impact of macroeconomic policy, all targeting at highlighting the information regarding the regions.

Thus, our study of the public/managerial discourse in Armenia shows that the tendences in the language development depend, to a great extent on the social, cultural processes leading to globalization.

\section{References and Notes:}

1. Знаменская Т.Л. Языковые гибриды как продукт стандартизации английского языка в сфере профессионального и международного общения. // Вопросы филологии, 2003, № 9, с.5-8.

http://www.ebiblioteka.ru/sources/article.jsp?id=5846239

2. Yernjakyan N.V., Gulyan A.M., On Some Extralinguistic and Paralinguistic Aspects of the Acquisition of English in Armenia // Ounum LtrqnıGtinn punånuqnıja nunngnıú: Łplima, 2002.

3. Fairclough N. Language in New Capitalism. // Discourse and Society. London, SAGE Publications, 2002, v.13(2), p.163-166.

4. Bomjh is a transformed Soviet reality survival, a Russian abbreviation, naming somebody who had no definite place to live and was liable to be sued by Soviet law for tramping. Currently it has acquired a new connotation denoting $n$ officially extreme form of poverty not to be punished legally.

5. In other words when those who have no power make sure that authorities either ignore them or pretend not to be ignoring, there arises no necessity of using the official language. In such cases we rather deal with a creation of one's own language than unawareness. We think that the following example of political folklore not only expresses the negative evaluation of the first Armenian president's policies but also shows the lack of a dialogue between the authorities and people. In the first stages of his presidency L.Ter-Petrossian's knoweledge of languages was estimated positively but in a later period, when people's 
frustration culminated as a result of his destructive policies, a folk joke went round as if Levon, being an expert in dead languages (not understandable to people), was driving the country to death.

6. Graham Phil. Hypercapitalism: Language, New Media and Social Perceptions of Value // Discourse and Society. London, SAGE Publications, 2002, v.13(2).

7. Our aim here is not to give a definition of the concept. We only define a bare outline of the phenomenon under consideration. It seems to us definitions won't make things clearer. On definitions see: Вежбицка А. Семантические примитивы. // Семиотика. Под.ред. Степанова Ю.С. Москва, Радуга, 1983, с. 227-230.

8. In terms of British house metaphor it is interesting to mention that a comparative survey of Ch.Dickens' "Bleak House", "Hard Times" (the 19th century reality) and Rosamund Pilcher's "Winter Solstice" (a modern bestseller) reveals no great difference between both traditional exterior/interior descriptions and psychological perceptions.

Actually the prestigious detached British houses can well contribute to this understanding of 'home' not only in architectural design but also isolation in terms of being impartial, indifferent.

As Tony Blair said, "globalization is a fact, the alternative is isolation, and the issue is not how to stop globalization but to use the power of the community to combine it with justice". Interestingly, isolation as an alternative is quoted by a representative of a culture where the cherished detached houses are likely to be providing individual's economic independence and privacy.

Condemning the nationalist movement leaders for propagating national isolation, Michael Gorbachev - a representative of Soviet culture, remarked, "We cannot isolate ourselves in our national flats".

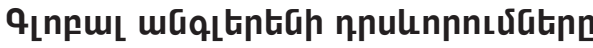 huslquluma anp hpnnnıpjua út?}

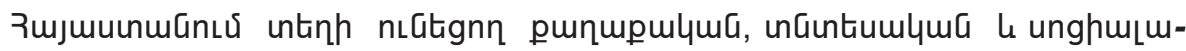

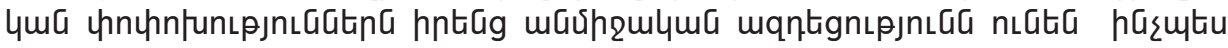

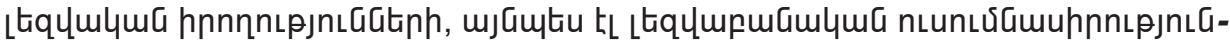

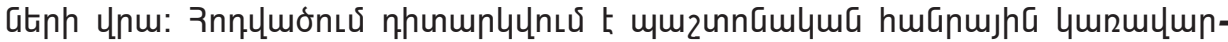

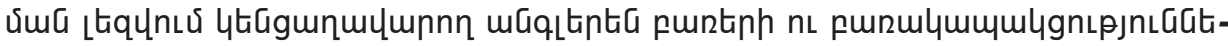

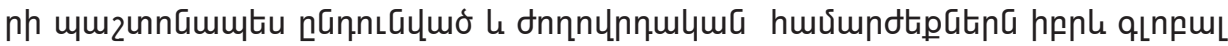

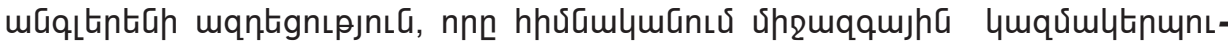

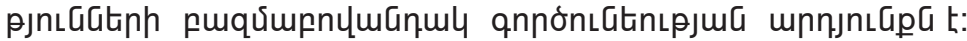

